\title{
Impact of COVID-19 Pandemic on Tourism Industry: Possible Reconciliation Strategy for Bangladeshi Tourism Industry
}

\author{
Mohammad Abu Horaira \\ College of Tourism and Hospitality Management (CTHM) \\ International University of Business Agriculture and Technology (IUBAT), Bangladesh
}

\begin{abstract}
The novel corona virus (COVID-19) has created a significant impact with international travel bans affecting over $90 \%$ of the world population and extensive restrictions on public gatherings and community mobility, tourism mainly comes to a halt in March 2020. Especially Tourism is at a risk to assess to counteract pandemics because of restricting mobility and social distancing. This paper is based on secondary document analysis from various journals, newspaper articles, World Health Organization (WHO), United Nations World Tourism Organization (UNWTO), Travel and Tourism Council (WTTC), Bangladesh Parjatan Corporation (BPC), reports, and papers of various tourism-related Bangladeshi organizations' (PATA, TEAB, TOAB etc.). The paper provides a critical assessment of the reported impacts of COVID-19 on global tourism, particularly on Bangladesh, and is looking for way-out and regional recovery suggestions against the uncertainty of COVID-19.
\end{abstract}

Keywords: COVID-19, Travel, Community, Mobility, Tourism, Pandemics, Global, Bangladesh

Corresponding author: Mohammad Abu Horaira; E-mail: horaira@iubat.edu DOI: https://doi.org/10.37227/ITHJ-2021-03-108

\section{Introduction}

Pneumonia of unknown cause detected in Wuhan, China, was first reported to the WHO Country Office in China on 31 December 2019. 41 patients with confirmed infections by a completely unique corona virus (COVID-19) had been admitted to hospitals in China (Huang et al., 2020) in early January 2020. Although the virus spread rapidly within the country's Wuhan region, it had been initially largely disregarded by political leaders in other parts of the planet (although intelligence services issued warnings of a potentially cataclysmic event; Washington Post, 2020). To contain the virus, Wuhan was put into lockdown (a combination of regional and individual quarantine measures), and case numbers in China stabilized at around 80,000 by mid-February (ECDC 2020). By then, global air transportation had already carried the virus to all or any continents and, by midMarch, it had been established in 146 countries. The total of confirmed infections worldwide quickly doubled, linked to many super-spreading events, like the ski destination Ischgl in Austria (Anderson et al., 2020; Johns Hopkins, 2020). From here, the infection 
rate accelerated through community transmission and, by 15 April, confirmed cases approached 2 million (with over 125,00 deaths) in over 200 countries (ECDC 2020). The total number of significant cases remains unknown as testing is restricted in most countries. With no vaccine to stop the disease and limited medical interventions available to treat it, most countries responded with various sorts of non-pharmaceutical interventions (NPI), including lockdown (home isolation, voluntary/required quarantine), social distancing (vulnerable or entire populations), closure of schools/universities and nonessential businesses/workplaces, cancelling or postponing events (i.e. major conferences and tradeshows, concerts and festivals, political debates and elections, sports seasons and therefore the summer Olympics), and bans on gatherings of individuals over certain numbers (Gössling, Scott, \& Hall, 2020).

International, regional and native travel restrictions immediately affected national economies, including tourism systems, i.e. international travel, domestic tourism, day visits and segments as diverse as air transportation, cruises, conveyance, accommodation, cafés and restaurants, conventions, festivals, meetings, or sports events (Tourism policy responses to the coronavirus (covid-19) 2020). With international aviation rapidly has been slowing down as a result of the crisis, and lots of countries imposing travel bans, closing borders, or introducing quarantine periods, international and domestic tourism declined precipitously over a period of weeks. Countries scrambled to return travellers home, which within the case of important outbound markets involved many thousands of citizens altogether parts of the world. As an example, on 23 March 2020, British Foreign Secretary urged British tourists to return home, "advising against about essential international travel", and highlighting that international travel is becoming harder with the closure of borders, airlines suspending flights, airports closing, exit bans and further restrictions being introduced daily FCO, 2020 (The Foreign \& Commonwealth Office). Cruise ships soon became the worst-case scenario for anyone stuck within the global tourism system. Starting with the 'Diamond Princess' on 1 February 2020, a minimum of 25 cruise ships had confirmed COVID-19 infections by 26 March 2020 (Mallapaty, 2020) and at the top of March, ten ships remained stumped unable to seek out a port that might allow them to dock. Idealized safe environments (Cordesmeyer \& Papathanassis, 2011) stumped became traps, with thousands of passengers held in-cabin quarantine and facing the challenge of returning home.

Within countries, the virus affected virtually all parts of the hospitality value chain. The impact of cancelled events closed accommodations, and pack up attractions became immediately felt in other parts of the availability chain, like catering and laundry services. Restaurants had to shut also, though, in some countries, a switch to take-away/delivery sales allowed some to continue operations. Reports on lay-offs and bankruptcies followed, with British airline FlyBe succumbing first to plug pressure, declaring bankruptcy on 5 March 2020 (Business Insider, 2020). Major airlines including Scandinavian Airlines (17 March 2020), Singapore Airlines (27 March 2020) and Virgin (30 March 2020), also as tour operators including German TUI (27 March 2020), have already requested tens of billions of US\$ in state aid.

The condition has become extraordinary. The scenario of the worldwide tourism system moved from over-tourism (e.g. Dodds \& Butler, 2019; Seraphin et al., 2018) to non-tourism within the space of months, intensely demonstrated by blogs and newspaper articles showing popular tourism sites in 'before' and 'after' photographs (Condé Nast Traveller, 2020). While some commentators already speculate on "What will travel be like after the Coronavirus", with some unrealistically optimistic perspectives already having 
proven wrong (Forbes, 2020), the overall belief is that tourism will rebound because it has from previous crises (CNN, 2020). However, there's much evidence that COVID-19 are going to be different and transformative for the tourism sector (Gössling, Scott, \& Hall, 2020). Governments only begin to know that, unlike other business sectors, tourism revenue is permanently lost because unsold capacity - as an example in accommodation can't be marketed in subsequent years, with corresponding implications for employment within the sector (Bakari, A rapid appraisal of covid-19 on global tourism).

In the perspective of Bangladesh, we've 12-15 international chain five-star hotels. Besides we've quite 600 three and two-star rated hotels and motels and lots of small hotels and homestays are providing service in every corner of Bangladesh who isn't on the list. These services are providing livelihood to many thousands of individuals (The impact of COVID-19 in tourism and hospitality industry of Bangladesh 2020).

According to the Pacific Asia Travel Association's Bangladesh chapter, till May 2020, the planet will face a loss of USD 97.05 billion within the tourism sector alone. Tourism experts assume if the lockdown situation continues like this, Bangladesh will need to face an economic loss of quite three billion BDT. Research shows that half 1,000,000 people that are directly or indirectly employed within the tourism and hospitality industry, are within the risk of losing their jobs (The impact of COVID-19 in tourism and hospitality industry of Bangladesh 2020).

As the whole country is during a lockdown situation, the amount of national also as a world tourist is zero. Normally more people tend to travel for travelling during summer so it's the foremost coveted season for travelling within the tourist destinations of Bangladesh. During a normal situation, it's difficult to urge the space booked, but now things is that the opposite. The Bangladesh flag carrier Biman Bangladesh Airlines cancelled all of their flight till the center of this year. Including Biman Bangladesh Airlines, other airlines companies who doing aviation business are undergoing serious economic losses. Some report declared that we'd need to wait till 2023 for going back normal situation for the aviation sector. To sum up, the tourism industry of Bangladesh, also because the whole world goes to face an enormous disaster and this disastrous situation will continue till the COVID-19 situation normalizes (The impact of COVID-19 in tourism and hospitality industry of Bangladesh 2020).

\section{Rationale and Objective of the Study}

The research outcome are going to be helpful for the concerned academic of the world, researchers, government policymakers, travel and tourism developers, investors moreover as other involved direct and indirect stakeholders of travel and tourism industry. This research paper may prolong resilience and way-out and regional recovery suggestions against the uncertainty.Against this background of a rapidly evolving global pandemic, this paper has three interrelated objectives. First, to critically review the literature on the impact of previous epidemic/pandemics on global tourism and compares these events to other sorts of global crises. This section also examines whether the COVID19 pandemic was an unknowable risk. Second, the paper provides a rapid assessment of the reported impacts of COVID-19 on global tourism including documented travel restrictions by each country and declines in aviation and accommodations, and differential regional impacts and implications for development were also examined. Finally the third goal is to seek way-out and regional recovery suggestions against the uncertainty. As soon because the virus is in check, there'll be an urge by many to travel back to business as was common, perhaps to overcompensate for losses by even more aggressive growth. Yet, the crisis holds 
important messages regarding the resilience of the tourism system, also concerning other ongoing crises that aren't as immediate, but potentially even more devastating than COVID-19, like global climate change. To overcome this example, the whole tourism sector and therefore the policymakers should undergo proper management and getting to restart their activities.

\section{Literature Review}

According to the World Travel \& Tourism Council (WTTC), the travel and tourism sector accounted for $10.3 \%$ of worldwide GDP and 330 million jobs in 2019 (Economic impact reports 2020). The world has seen high growth within the last decade, which may be largely attributed to factors like rising disposable incomes, the emergence of low-cost carriers, simple travel through internet-based services and therefore the relaxation of visa regulations.

According to the WTTC estimates, the world contributed $\$ 234$ billion or $6.6 \%$ of the region's GDP in 2019 in South Asia region (WTTC, Economic Impact Report 2020). The pandemic couldn't have come at a worse time for Nepal's tourism industry, which has almost collapsed since the outbreak within the region and as a matter of fact the government of Nepal had declared 2020 as Visit Nepal Year, announcing a national campaign with an annual target of achieving 2 million tourist arrivals (Pun, 2019). With the country's borders closed to adventure-seeking mountaineering crowds, the direct actors along within the tourism value chain (tour operators, trekking agencies, mountain guides and Sherpas) have lost their only source of income (Darbari, Gupta, Bikhchandani, \& Ramesh, 2020).

Similarly, the Republic of Maldives is significantly susceptible to external shocks, and tourism constitutes a 3rd of the small island state's national revenue. Neeza Imad, Minister of State for Economic Development of Maldives stated that COVID-19 has had a devastating impact on our economy, particularly concerning SMEs that account for many of the tourism-related employment (Economy SF6 circuit in MALDIVES 2020). As a result of the continued crisis, the international fund has projected that the country's economy will contract by $8.1 \%$ in 2020 (Maldives and the IMF 2020).

The World Tourism Organization's (UNWTO) has made a compilation of country and international policy responses, and has put the compilation during a site named "Tourism Support Measures". The location reveals that the Bangladesh tourism industry will face a loss of about Tk40 billion (USD 470 million) this year (UNWTO, 2020).Due to the present COVID-19 global pandemic, international flights are minimized. Many scheduled tour packages from abroad are cancelled. Moreover, domestic travellers are unlikely to travel during the official shutdown period. Additionally, intercity public transportation is additionally unable to work. As result, the tourism sector has become vulnerable.

According to the World Bank collection of development indicators, international tourism, number of arrivals in Bangladesh was reported at 323000 in 2019 (The World Bank, International tourism, number of arrivals - BANGLADESH 2021). During the 20112017 periods, WTTC reported that Bangladesh's travel \& tourism sector generated approximately a yearly 2.23 million jobs. The tourism sector directly provides a livelihood for the stakeholders, involved in the travel and tourism business directly and indirectly. The COVID-19 outbreak has also restricted business travel. As a result, many tourismrelated sectors like hotels, restaurants and transportation are affected (Hossain, 2020). The Tour Operation Association of Bangladesh (TOAB) forecasted that Bangladesh would see a loss of Tk57 billion during this sector. According to the Civil Aviation Authority of Bangladesh, the government has suspended on-arrival visas for all nationalities. All 
international flights coming back from Bahrain, Bhutan, Hong Kong (SAR China), India, Kuwait, Malaysia, Maldives, Oman, Qatar, Saudi Arabia, Sri Lanka, Singapore, Thailand, Turkey, United Arab Emirates or the UK are suspended until 14 May (Bangladesh: Suspension of international and domestic Flights extended to May 7 lupdate 9 2020; Karim, Haque, Anis \& Ulfy, 2020). Regular visa holders arriving in Bangladesh need to submit a health certificate that has been obtained within 72 hours. A Bangladeshi citizen who submits a health certificate has got to remain in-home or self-quarantine for 14 days. Without a health certificate, there'll be institutional quarantine for 14 days (U.S. Embassy Dhaka, 2020). As a result, the tourism industry, which entirely depends on the tourists in every country i.e., India, Sri Lanka, Bhutan, Malaysia, Bangladesh and in other country may face problem to retain competitive (Karim et al., 2020; Islam, Jantan, Yusoff, Chong, \& Hossain, 2020).

According to Dhaka Tribune (2021), the government of Bangladesh has announced a stimulus package to support the tourism sector, where banks will provide loans at 9 per cent interest and the government will bear 4.5 per cent interest and therefore the remaining 4.5 per cent are going to be borne by the business and he government will provide 30 billion (BDT) capital for the COVID-19 affected industries and repair sector institutions through four packages.

\section{Tourism}

UNWTO defines tourism that encompasses the activities of an individual travelling to and staying in places outside their normal place of residence for less than one consecutive year for leisure, business, and other purposes. Tourism and travel are not the same. So as for tourism to take place, there must be a displacement: an individual who wishes to travel, using any form of means of transportation, it might even travel on foot: nowadays, it's often the case for unprivileged social class and happens even in additional developed ones, and concerns pilgrims, hikers, adventurists, campers. But all travel isn't tourism. Essentially, it refers to all or any or any activity related to the shortterm movement of people to locations far from where they typically reside. It is one of the largest industries of the world and thus, the economies of the many nations are driven, to an outsized extent, by their tourist trade (Tourism - definition, types \& forms, history \& importance 2020).

\section{Tourism and Pandemic Saga Tourism Industry}

The tourism industry is often defined as the set of industries that facilitate by delivering the infrastructure, products, services, and changes travelling for a mixture of purposes and travelling to the places of the leisure and business concentrations. The tourism industry is all about providing necessary means to help tourists throughout their travelling (Market Width, 2018). It is also a wide-ranging industry, which incorporates the hotel industry, the transport industry and a variety of additional industries or sectors and it is vital to know that the tourist industry is linked to movement to different locations, based not only on leisure, but also business, and a few additional travel motivators (Tourism industry: Everything you need to know about tourism: Revfine 2021). With that being said, according to the most common definitions, the tourism industry does not cover activities related to travel where the person intends to stay in their destination for longer than one year. As an example, this means that expatriate and long-term international students are not technically 
classed as tourists (Tourism industry: Everything you need to know about tourism: Revfine 2021).

Transportation, tour operators, travel agents, and accommodation are mainly the sectors of tourism supply and these are examined and the importance of cross-country integration between firms is highlighted. According to Horaira (2017), tourism depends greatly on an authentic socio-cultural and an unrestrained natural environment.

\section{Tourism Industry in Bangladesh}

Tourism brings numerous benefits and advantages to hosting a country or a community, but mostly it depends on its nature and how it is defined and structured. Tourism significantly contributes towards the complete growth and development of a country by bringing numerous economic value and benefits as well as helping in build a country's brand value, image, and identity. Earlier to pandemic WTTC (2019) reported that Travel \& Tourism (including its direct, indirect and induced impacts) computed for 1 in 4 of all new jobs created across the world, $10.6 \%$ of all jobs (334 million), and 10.4\% of global GDP (US\$9.2 trillion) and in the meantime, international visitor spending increased to US\$1.7 trillion in 2019 (6.8\% of total exports, $27.4 \%$ of global services exports). The contribution of travel and tourism to GDP (\% of GDP) for Bangladesh in 2019 was $4.4 \%$, although Bangladesh contribution of travel and tourism to GDP (\% of GDP) fluctuated substantially in recent years, it tended to increase through the 2000 - 2019 period ending at $4.4 \%$ in 2019. The tourism industry not only plays as a growth driver for a country, but also for the economy, and social progress (Thakur, 2018). Tourism has evident impacts in several industries directly, and much more indirectly through tourism spends, and therefore, tourism plays an important role in a country, for a community, for the society, for the economy, for growth and development, nature and environment, and the world (Manzoor, Wei, Asif, Haq, \& Rehman, 2019). Moreover, tourism helps in understanding the cultural diversity, geographical, and historical facts of different region and community, and as a result, tourism plays a major role in the social, cultural, economic, and environmental development of a nation (Kiper, 2013).

The tourism industry is a multifaceted industry that comprehends a wide range of businesses, organizations, and government agencies and they collectively work at different levels to deliver different tourism products and packages and same time they contribute at all levels as vice-versa from initial destination marketing through to the ground level to ensure the overall holiday experience of the customer (Tourism industry: Everything you need to know about tourism: Revfine 2021). The tourism industry is also classified as a tertiary industry that provides service for a charge (Pettinger et al., 2020). There are four main characteristics of tourism, and these are intangibility, perishability, inseparability, and variability that are in contrast to those of physical products that are produced, stored, later sold, and stilled later consumed (Dutta, 2014). The tourism industry is well known and distinguished with a combination of different activities and services that offer transportation, accommodation, food, shopping, attractions, and entertainment and hospitality services to travellers (George, 2021). All these mooted activities can increase the economic development process by creating jobs, developing infrastructure and entrepreneurial skills, improving the balance of payments, earning foreign exchanges, and export revenues (Cook, Yale, \&Marqua, 2006).

The Tourism industry in Bangladesh has largely developed based on the major cities i.e. Dhaka, Sylhet, Chittagong, Cox's Bazar, Khulna are the major cities and tourist destinations in Bangladesh along with other destinations (Deb \& Nafi, 2020). Moreover, 
Cox's Bazar is understood because of the tourism capital in Bangladesh. Most of the tourism infrastructure and super structures are developed in these cities and these cities largely contribute to the tourism economy (Roy \& Hoque, 2015). Both the inbound and outbound tourism market has increased significantly in the last few years (Glaesser, Kester, Paulose, Alizadeh, \& Valentin, 2017). International inbound leisure travel trips tourists' arrival in Bangladesh recorded 1.02 million tourists in 2017 and also recorded 0.83 million in 2016 (Tourism Sector (BD Economy) 2020). Bangladeshi residents' outbound leisure trips are projected to approximately 2.6 million trips by 2021, compared to the 2016 estimate of 2.3 million (Bangladesh: Number of outbound travellers 2021). The pandemic has an adverse effect on inbound tourism in and outbound Bangladesh due to the corona virus (Covid-19) (Deb \& Nafi, 2020).

\section{Pandemics and Tourism}

If we consider the last fifteen years between 2000 and 2015, global tourism has been exposed to a wide range of pandemic crises such as the Severe Acute Respiratory Syndrome (SARS) outbreak (2003), Middle East Respiratory Syndrome (MERS) outbreak (2015). None of them led to a longer-term decline in the global development of tourism, and some of them are not even notable with only SARS (-0.4\%) and the global economic crisis $(-4.0 \%)$ leading to declines in international arrivals (World Bank 2020a, 2020b). This would recommend that tourism as a stream has been resilient to external impacts and there is much evidence that the impact and recovery from the COVID-19 pandemic will be only a matter of time.

The correlation between pandemics and travel is innermost to indulgent health security and global change (Burkle, 2006). Although tourism research has developed a minimum of a cursory realization of the potential systemic effects of worldwide global climate change, there has not been an equivalent appreciation of the systemic effects of pandemics, with studies tending to specialize in individual country impacts, instead of the system-level challenges and vulnerability. Several studies have demonstrated the important role of aviation in accelerating and amplifying propagating influenza and corona viruses (see Brown et al., 2016 for a review). However, to an extent, the increase and fall of educational interest within the correlation among tourism and pandemics is reflective of that of the broader industry and also governments, as long as tourism has been suffering from disease outbreaks numerous times since the turn of the millennium. Most extensively, there were several warnings that pandemics created a serious threat to society and tourism (Gössling, 2002; Scott \& Gössling, 2015; Hall, 2006, 2020; Page \& Yeoman, 2007) and from tourism and health researchers (Bloom \& Cadarette, 2019; Fauci \& Morens, 2012), and also from the government agencies (National Academies of Sciences, Engineering, and Medicine, 2017, 2018) as well as from institutions (Jonas, 2014; International Bank for Reconstruction and Development, 2012).

According to the researchers, the key factors for the increasing pandemic threat in the 21st century are fast-growing and movable world population, urbanization trends following society, industrialized food manufacturing in widespread value chains, increased consumption of transcendental foods, and the progress of global transport networks acting as vectors in the development of pathogens (Pongsiri et al., 2009; Labonte et al., 2011).

Disease outbreaks like SARS, Ebola, Marburg, Hantavirus, Zika and Avian Influenza (Bird Flu) are all outcomes of anthropogenic impacts on ecosystems and biodiversity (Petersen et al., 2016; Schmidt, 2016; International Bank for Reconstruction and Development, 2012). As Wu et al. (2017, p.18) stated that high-risk areas for the 
emergence and spread of communicable disease are where wild disease receptacle, agricultural practices that increase contact between wildlife and livestock, and cultural practices that increase contiguity between humans, wildlife, and livestock.

The drastic globalization changes are resulting in the increasing outbreaks of the major epidemics and pandemics. It's generally recognized that the 20th century experienced three pandemics. The so-called 'Spanish' flu or influenza of 1918-19: the 'Asian' flu (H2N2) of 1957 and therefore, the 'Hong Kong' flu of 1968. The twenty-first century has already experienced four pandemics: SARS in 2002, 'Bird' flu in 2009, MERS in 2012, and Ebola which peaked in 2013-14, with the emergence pandemic outbreaks since 2000 believed to be strongly linked with the worldwide change factors mentioned above (Coker et al., 2011; Greger, 2007; Wu et al., 2017).

The SARS outbreak in 2003 was defined as a plague by the WHO, with most cases in China and Hong Kong and with clusters of cases in Taiwan and Canada also. SARS has been studied from a tourism context. Siu and Wong (2004) reported that the general economic impact for Hong Kong wasn't as severe needless to say, but that travel, tourism and retail were substantially affected as a result of the short-term decline in visitation. SARS had an overall estimated global economic cost of US $\$ 100$ billion, and US\$48 billion in China alone (McKercher \& Chon, 2004; Siu \& Wong, 2004).

Swine influenza was defined as an epidemic although was a comparatively mild instance. However, this pandemic resulted in nearly 284,000 deaths worldwide in 2009 (Viboud \& Simonsen, 2012). Russy and Smith (2013) examined the results of the pandemic on tourism in Mexico, suggesting that losing almost 1,000,000 overseas visitors over five months translated into losses of around US $\$ 2.8$ billion, with European markets being the slowest to return.

Two other pandemics were active at the time of the emergence of COVID-19. The primary is that the highly lethal MERS, a viral respiratory illness caused by a corona virus (MERS-CoV), identified in Egypt in 2012 (Berry et al., 2015). MERS has received significant attention within the travel medicine literature due to the massive number of individuals who engage within the annual hajj pilgrimage to Saudi Arabia (Al-Tawfiqef et al., 2014). The second is Ebola, which has a mean death rate of roughly $50 \%$ across the various waves of the disease (Chowell \& Nishiura, 2014). The primary outbreak occurred within the Democratic Republic of Congo (DRC) and Sudan in 1976 with subsequent outbreaks occurring in West Africa in 2014-16 and therefore the DRC in 2018-19. The Ebola outbreak was regarded as a negative perception for African destinations, that were unaffected by Ebola (Maphanga \& Henama, 2019; Novelli et al., 2018). The Ebola and MERS outbreaks were significant in raising awareness on the threat of worldwide pandemics; however, that threat wasn't recognized outside of these concerned with health security. Since the Ebola outbreak, few doubted that major epidemics and pandemics will strike again and few would argue that the planet is satisfactorily prepared (Fan et al., 2018, p.129).

One of the primary realizations of research on pandemics is that travel is the prime factor to epidemiology and disease surveillance (Hon, 2013; Khan et al., 2009). This also means recognizing that travel and tourism is both a contributor to disease spread and its economic consequences and is dramatically suffering from it due to Nonpharmaceutical Interventions (Nicolaides et al., 2019).

The Spanish Flu is mentioned because Spain was the first country in which the Spanish Flu was an outbreak and Spain was widely indicated because wartime restrictions on the media were still in place in many countries. The 1918-19 pandemic infected over 
500 million people (nearly one-third of the then global population) and resulted in an estimate of between 21 to 100 million deaths (nearly $1 \%-5 \%$ of the world's then population) (Jeffery \& David, 2006; Johnson \& Mueller, 2002), and the pandemic travelled around the world in three waves and can consequently be mentioned because of the primary "modern" pandemic characterized by impetuous motion through global transportation system (Killingray, 2003; Taubenberger \& Morens, 2006).

The Spanish Flu is a crucial analogue for COVID-19 not only due to its similar virulence but also because many of the NPIs that were applied then are getting used to mitigate COVID-19 (e.g. quarantine, travel restrictions) (Ferguson et al., 2006). Research suggests that the appliance of such measures within the case of the 1918-19 pandemic reduced death rates by approximately 50\% (Hatchett et al., 2007) and if NPI interventions were maintained then mortality was significantly reduced (Markel et al., 2006, 2007). However, as Hatchett et al. (2007) noted, interventions were rarely maintained for extended than six weeks with the virus continuing to spread once restrictions were relaxed, which then led to public questioning on the NPIs effectiveness.

Given their recognized massive impacts, there is a surprisingly limited assessment of the economic effects of pandemics (Fan et al., 2018), with the majority of studies conducted at a national level (Keogh-Brown et al., 2010a, 2010b; Prager et al., 2017). The bulk of economic studies of influenza are also generally undertaken in high-income OECD countries (Peasah et al., 2013). During a widely cited report, McKibbin and Sidorenko (2006) estimated that the worldwide economic cost of a Spanish Flu type pandemic would be on the brink of $12.6 \%$ of GDP, with the best impact on non-OECD countries. during a newer assessment, Fan et al. (2018) found that at a worldwide scale, a moderately severe influenza pandemic would end in 720,000 deaths and a price of $0.6 \%$ of worldwide income (due to income loss and mortality). Table 1 compares the economic consequences of three different pandemic scenarios (Burns et al., 2006; McKibbin \& Sidorenko, 2006), also as a worst-case scenario at the upper end of the severity of the Spanish Flu. A recent update by McKibbin and Fernando (2020) suggested that even a Hong Kong Flu type pandemic would scale back global GDP by around US\$2.4 trillion and a Spanish flu-type outbreak reduces global GDP by over US\$9 trillion in 2020.

Hotels round the world face cancellations of bookings because of the pandemic crisis. As a result, the Hotel industry lost US\$ 150 billion, mostly affecting the workers within the industry. So, the impacts of the COVID-19 outbreak on the hospitality industry are often evaluated using room booking cancellations and therefore the status of hotel industry workers. The hotel industry altogether world regions recorded a huge drop by the worldwide revenue per available room, e.g., Asia (-67.8\%) and Europe (-61.7\%). Also, the worldwide occupancies in countries decreased significantly in March 2020, from 20\% to over $70 \%$ worldwide (UNWTO, 2020a). The negative relationship between corona virus outbreak of the tourism sector has been illustrated by prior studies supported the Ebola virus and therefore the outbreak of SARS (Kongoley-MIH, 2015; Zeng et al., 2005). The COVID-19 epidemic is that the most severe virus outbreak, which profoundly influences the planet economy compared to the previous outbreaks. The UNWTO data further illustrated that 850 million to 1.1 billion fewer international tourist arrivals with a loss of export revenues from tourism 910 billion US \$ to 1.2 trillion US \$ in 2020 thanks to the corona virus epidemic worldwide. It also enhanced that 100 to 120 million direct tourism jobs are in danger. The above findings revealed a negative relationship between the COVID-19 outbreak and therefore the tourism sector. 


\section{COVID-19 and Tourism}

The disease COVID-19 caused by a replacement strain of corona virus called Severe Acute Respiratory Syndrome Corona Virus 2 (SARS-CoV-2). It has had a greater impact on tourism and travel behavior than any known disease outbreak in living memory. Outside the general public health sphere tourism has become one among the most public faces of COVID-19 within the international media. The character of the tourism system means tourism has both contributed to the spread of the disease and experienced the repercussions of the disease alongside all parts of the tourism value and provides chains. The disease's global proximity and consequently the necessity of classic disease control within the sort of quarantine, reduced mobility and isolation have had a dramatic effect on international and domestic tourism alike alongside a variety of sector-specific impacts, including transport, travel and booking agencies, hospitality, restaurants, conventions and events, and attractions.

\section{Methodology}

The secondary research approach i.e. qualitative approach was adopted to address the objectives of this study (Hox, \& Boeije, 2005; Largan, \& Morris, 2019). This study was basically qualitative in nature, and the required data and information were collected through document analysis (Martins, Cunha \& Serra, 2018; Largan, \& Morris, 2019; Islam, Hunt, Jantan, Hashim, \& Chong, 2020). For this purpose, a thorough literature review has been conducted. To obtain the reliable secondary data from various journals, newspaper articles, World Health Organization (WHO), United Nations World Tourism Organization (UNWTO), Travel and Tourism Council (WTTC), Bangladesh Parjatan Corporation (BPC), reports and papers of various tourism-related Bangladeshi organizations' (PATA, TEAB, TOAB etc.) were consulted carefully.

\section{Discussion, Analysis and Recommendation}

The COVID-19 pandemic must be regarded for a critical reconsideration of the worldwide volume growth model for tourism, for interrelated reasons of risks incurred in global travel also because of the sector's contribution to climate change. The success stories of the Tourism Industry has been denominated by all dominant tourism organizations - UNWTO, ICAO, CLIA, or WTTC - as growth in tourism numbers. This viewpoint has already been doubted within the conditions of the worldwide financial crisis (Hall, 2009) and because the challenges of over-tourism, global climate change and COVID-19 pandemic further illustrate, this perspective is outdated. Even though growth lobbyists regularly pay lip service to climate change and the SDGs, there is no evidence-based strategy for climate change mitigation, and an overall silence regarding pandemic and other risks the worldwide tourism system imposes on itself and therefore the global economy (Scott et al., 2019). Growth advancement agendas are emerging to be driven by individuals and large businesses profiting from such growth models. Especially, these comprehending industries represented by ICAO, CLIA, or WTTC, the platform economy (e.g. Booking and AirBnB), aircraft manufacturers such as Boeing and Airbus, national DMOs, and certain giant tourism organizations. The UNWTO is a prominent exposition of a supranational organization that is responsible for advancing the SDGs in their perpetuity, yet in its current form represents a growth advocacy platform (Gössling et al., 2016; Hall, 2019).

Above all, the COVID-19 crisis should be taken as an opportunity to review and reconsider the tourism's growth approach, and to query, the relevance of more arrivals suggested substantial benefits. This may begin with a review of the positive outcomes of the COVID-19 pandemic. For example, according to Simple Flying, as many of the old 
fashioned aircraft are grounded in 2020 due to COVID-19 and there is a notable decline in demand, airlines have begun to end old and inefficient aircraft (Hayward, 2020). Video conferences, a missed opportunity to reduce transport demand (Banister \& Stead, 2004) for years, has become widely adopted by home office workers, including students forced into distance learning, and business travellers avoiding non-essential air travel. As affirmed by Cohen et al. (2018), many business travellers will welcome opportunities to fly less. Importantly, even high-level exchanges, like the G20 Leader's meeting on 26 March 2020, have for the primary time been organized through videoconference (European Council, 2020). After months of these new work arrangements, for how many organizations and workers will perceive the benefits of continued or partial adoption? More generally, perception of mobility can also have changed in everyday contexts, as countries without full lockdown responses appear to possess seen a big rise in cycling and outdoor activities.

The tourism industry is an umbrella industry networked with many other sectors within the economy including hotel, community-level operations, education, financial, agriculture, medical, travel and transportation, construction, land, retail, and the other way around. Because the whole world is suffering from this COVID 19 pandemic, the tourism sector is one among the foremost victimized of it. So, it's time to debate about the difficulty and is available up with realistic recovery initiatives. Therefore, a few realistic recovery strategies for the tourism industry in Bangladesh within the post-viral world and these can be:

1. Smart quarantine and tracing tools (digital) could be used to mark healthy and riskfree travellers, such tolls like introducing on-arrival Smart SIM (Subscriber Identification Module) and Mobile Apps for international travellers.

2. World Tourism Organization (UNWTO), concerning the special attention, has already launched several practices to save the essentials of tourism industry at present. The special campaign named "\#Travel Tomorrow - , has become the common thread that runs through the World Tourism Organization's response to the current crisis, highlighting the enduring values of tourism. E.g. "By staying home today, we can travel tomorrow".

3. Sharing current and happening issues and knowledge's on tourism with necessary stakeholders globally and locally.

4. Re-branding of tourism destinations after the pandemic situation highlighting the positive elements during the outbreak.

5. Hoteliers, travel agents and other service providers should continuously keep in touch with key travellers and customer base during the outbreak to sustain linkage.

6. Community-Based Tourism (CBT) should be properly encouraged with adequate resources to mitigate and recover from outbreaks.

7. Service providers and human resource within the tourism and hospitality industry must be sufficiently trained and prepared for the recovery to retain and collaborate with guests/ potential guests appropriately to avoid uncertainties and risks.

8. Ensuring responsible and ethical use of electronic, social, and mass media.

9. Following the advice and announcements from global institutional structures like UNWTO, WTTC and WHO to recover the industry level globally.

10. National tourism authorities must continuously collaborate with the global tourism authorities to help the tourism industry prepare and respond to global health emergencies. 
Besides the strategically recommendations, individual efforts from the citizens, direct involvement of the nation's public health experts, and international supports are also required.

However, based on regional and geographical experiences where human movements have already opened, greater public-private cooperation will be needed to establish and conform to health and safety standards and protocols. While communicating to potential travellers it should be with clarity and consistency to potential travellers to rebuild their trust and confidence. It is high time to maintain close coordination among sectors such as aviation, railways, tourism and hospitality to ensure insurance that will be needed to adapt to the evolving health situations in particular countries.

Travellers also require doing their part by developing them to resist the uncertainties while safeguarding. Subsequently, through the process, they must suit themselves with changing regulations that help countries manage fluctuations within the number of COVID-19 cases, which will definitely increase as borders open up and consequently the world becomes mobile again. With the magnitude of the COVID-19 pandemic, there is no need to be an urgency to return to business-as-usual. When the crisis over, the experiences of coronavirus pandemic crisis can be taken as an opportunity to reanalyze a transformation of the global tourism system for strengthening the SDGs. COVID-19 startled the whole world and given salient lessons to the tourism industry, tourism researchers and policymakers about the effects of global change. This global calamity has forced a challenge to collectively learn to hasten the transformation of sustainable tourism.

\section{Conclusion}

This study explored significant insights concerning the impact of the COVID-19 pandemic on the tourism industry especially the Bangladeshi tourism industry. A qualitative research approach was conducted and therefore the required data and information were collected through document analysis and literature review. The study has found the COVID-19 crisis should be taken as a chance to review and reconsider the tourism's growth approach, and to query, the relevance of more arrivals suggested substantial benefits. This might begin with a review of the positive outcomes of the COVID-19 pandemic. Hence, the paper can be a significant platform for academicians, researchers, industry planners and government officials in developing their decisions and various initiatives to make the tourism industry resilient in response to a disaster like the COVID-19 pandemic.

\section{Limitations of the Study and Future Directions}

The study was prepared primarily based on secondary sources relying on published literature and publicly available information. Therefore, the insights of the paper should be used cautiously. However, future studies can be conducted in different perspectives and different industries to enrich current literature regarding the impact of the COVID-19 pandemic. Furthermore, more specific empirical researches with quantitative tools and analysis are also recommended for future researchers. Moreover, future researchers are also recommended to conduct comparative studies along with exploration of coping strategies in response to a crisis like the COVID-19 pandemic. 


\section{References}

Al Jazeera. (2020, June 03). Coronavirus: Travel Restrictions, BORDER shutdowns by country. Retrieved Jun 12, 2020, from https://www.aljazeera.com/news/2020/6/3/coronavirus-travel-restrictions-bordershutdowns-by-country

Al-Tawfiq, J. A., Zumla, A., \& Memish, Z. A. (2014). Travel implications of emerging coronaviruses: SARS and mers-cov. Travel Medicine and Infectious Disease,12(5), 422-428. doi:10.1016/j.tmaid.2014.06.007

Ashraf, G. (2021, April 21). Bangladesh tourism sector to incur TK 97b business Loss, PATA forecasts. Retrieved Nov 28, 2020, from https://en.prothomalo.com/bangladesh/bangladesh-tourism-sector-to-incur-tk-97bbusiness-loss-pata-forecasts

Bakari, S. J. (2021). A rapid appraisal of covid-19 on global tourism. Retrieved April 09, 2021 , from https://www.researchgate.net/publication/350124131_A_Rapid_Appraisal_of_COVI D-19_on_Global_Tourism

Bangladesh: Number of outbound travelers 2021. (2021, March 29). Retrieved April 11, 2021, from https://www.statista.com/statistics/726873/number-of-outboundtravelers-bangladesh/

Bangladesh: Suspension of international and domestic Flights extended to May 7 /update 9. (2020, April 28). Retrieved July 03, 2020, from https://www.garda.com/crisis24/news-alerts/336766/bangladesh-suspension-ofinternational-and-domestic-flights-extended-to-may-7-update-9

Banks told not to charge more than $4.5 \%$ interest on stimulus funds. (2021, January 12). Retrieved Jan 19, 2021, from https://www.dhakatribune.com/business/2021/01/13/banks-told-not-to-charge-morethan-4-5-interest-on-stimulus-funds

Beach, B., Clay, K., \& Saavedra, M. (2020). The 1918 influenza pandemic and its lessons FOR COVID-19. doi:10.3386/w27673

Belderok, S., Rimmelzwaan, G. F., Van den Hoek, A., \& Sonder, G. J. (2013). Effect of travel on influenza epidemiology. Emerging Infectious Diseases,19(6), 925-931. doi:10.3201/eid1906.111864

British airline Flybe declared BANKRUPT; dozens of Schiphol flights canceled. (2020, March 05). Retrieved Jun 19, 2020, from https://nltimes.nl/2020/03/05/britishairline-flybe-declared-bankrupt-dozens-schiphol-flights-canceled

Chowell, G., \& Nishiura, H. (2014). Transmission dynamics and control of ebola virus disease (evd): A review. BMC Medicine,12(1). doi:10.1186/s12916-014-0196-0

Cook, R. A., Yale, L. J., \& Marqua, J. J. (2006). Tourism: The business of travel. Upper Saddle River, NJ: Pearson Prentice Hall.

Coronavirus disease (covid-19): Similarities and differences with influenza. (2020, March 17). Retrieved Dec 15, 2020, from https://www.who.int/news-room/q-adetail/coronavirus-disease-covid-19-similarities-and-differences-with-influenza

Darbari, R. (2020, August 24). Travel and tourism RECOVERY: A perspective for South Asia and lessons for other regions in the age of covid-19. Retrieved November 06, 2020, from https://www.weforum.org/agenda/2020/08/travel-and-tourism-recoverysouth-asia-covid19-pandemic-economy-india-nepal-bhutan-sri-lanka/.

Deb, S. K., \& Nafi, S. M. (2020). Impact of Covid-19 pandemic on Tourism: Perceptions from Bangladesh. SSRN Electronic Journal. doi:10.2139/ssrn.3632798 
Definition of Tourism (UNWTO definition of Tourism) / what is Tourism? (2010, March 30). Retrieved Jan 10, 2021, from https://www.tugberkugurlu.com/archive/definintion-of-tourism-unwto-definition-oftourism-what-is-tourism

Department, P., \& 29, M. (2021, March 29). Bangladesh: Number of outbound travelers 2021. Retrieved Nov 06, 2020, from https://www.statista.com/statistics/726873/number-of-outbound-travelersbangladesh/

Dutta, D. (2014). Services Marketing. Retrieved April 09, 2021, from https://www.slideshare.net/DebayanDuttaCFP/services-marketing-37164131

Economic Impact Reports. (2020). Retrieved Jan 10, 2021, from https://wttc.org/Research/Economic-Impact

Economics in the time of covid-19 - vox. (2020). Retrieved April 10, 2020, from https://voxeu.org/system/files/epublication/COVID-19.pdf

Evaluation of influenza vaccine effectiveness a guide to the design and interpretation of observational studies. (2017, December 14). Retrieved Nov 06, 2020, from https://www.who.int/immunization/documents/978-92-4-151212-1/en/

George, R. (2021). Characteristics of Tourism and Hospitality Marketing. Marketing Tourism and Hospitality, 33-61. doi:10.1007/978-3-030-64111-5_2

Glaesser, D., Kester, J., Paulose, H., Alizadeh, A., \& Valentin, B. (2017). Global travel patterns: An overview. Journal of Travel Medicine, 24(4). doi:10.1093/jtm/tax007

Gómez, M. I., \& Ricketts, K. D. (2013). Food value chain transformations in developing countries: Selected hypotheses on nutritional implications. Food Policy,42, 139-150. doi:10.1016/j.foodpol.2013.06.010

Gössling, S., Scott, D., \& Hall, C. M. (2020). Pandemics, tourism and Global change: A Rapid assessment of covid-19. Journal of Sustainable Tourism, 29(1), 1-20. doi:10.1080/09669582.2020.1758708

Hafsa, S. (2020). Impacts of Covid-19 pandemic on tourism \& hospitality industry in Bangladesh. SSRN Electronic Journal. doi:10.2139/ssrn.3659196

Hayward, J. (2020, December 28). The rise and fall of The Boeing 747 jumbo jet. Retrieved April 16, 2021, from https://simpleflying.com/jumbo-jet-rise-and-fall/

History.com Editors. (2010, October 12). Spanish flu. Retrieved April 16, 2021, from https://www.history.com/topics/world-war-i/1918-flu-pandemic

Horaira, M. A. (2017). Tourism in Kuakata: A CURBED RARENESS in Global Village. American Journal of Trade and Policy,5(2), 67-72. doi:10.18034/ajtp.v5i2.436

Horaira, M. A. (2020). The economic impact of tourism on to the community of kuakata. Asian Journal of Humanity, Art and Literature,7(1), 43-58. doi:10.18034/ajhal.v7i1.500

Hossain, M. (2020, May 06). Covid-19 to COST Bangladesh tourism sector Tk40bn: UNWTO. Retrieved Sep 09, 2020, from https://tbsnews.net/economy/covid-19-costbangladesh-tourism-sector-tk40bn-unwto-78118

Hox, J. J., \&Boeije, H. R. (2005). Data collection, primary versus secondary. Encyclopedia of Social Management: Vol 1, Elsevier.

Hunter, M. (2020, March 30). What will travel look like after coronavirus? Retrieved Jun 19, 2020, from https:/edition.cnn.com/travel/article/coronavirus-travel-industrychanges/index.html

Impact of covid-19 on tourism industry: A review. (2020, September 16). Retrieved Jan 10, 2021, from https://mpra.ub.uni-muenchen.de/102834/1/MPRA_paper_102834.pdf 
Islam, M. A., Jantan, A. H., Yusoff, Y. M., Chong, C. W., \& Hossain, M. S. (2020). Green Human Resource Management (GHRM) practices and millennial employees' turnover intentions in tourism industry in Malaysia: Moderating role of work environment. Global Business 1-21. https://doi.org/10.1177\%2F0972150920907000

Islam, M. A., Hunt, A., Jantan, A. H., Hashim, H., \& Chong, C. W. (2020). Exploring challenges and solutions in applying green human resource management practices for the sustainable workplace in the ready-made garment industry in Bangladesh. Business Strategy \& Development, 3(3), 332-343. https://doi.org/10.1002/bsd2.99

Karim, W., Haque, A., Anis, Z., \& Ulfy, M. A. (2020). The movement control order (MCO) for covid-19 crisis and its impact on tourism and hospitality sector in malaysia. International Tourism and Hospitality Journal, 3(2), 1-7. https://doi.org/10.37227/ithj-2020-02-09

Kiper, T. (2013, July 01). Role of ecotourism in sustainable development. Retrieved May 10,2021 , from https://www.intechopen.com/books/advances-in-landscapearchitecture/role-of-ecotourism-in-sustainable-development

Largan, C., \& Morris, T. (2019). Qualitative secondary research: A step-by-step guide. Sage.

Lee, J., \&McKibbin, W. J. (2004). Globalization and disease: The case of sars. Asian Economic Papers,3(1), 113-131. doi:10.1162/1535351041747932

Manuja, B. K., Manuja, A., \& Singh, R. K. (2014). Globalization and livestock biosecurity. Agricultural Research, 3(1), 22-31. doi:10.1007/s40003-014-0097-7

Manzoor, F., Wei, L., Asif, M., Haq, M., \& Rehman, H. (2019, October 8). The contribution of sustainable Tourism toEconomic growth and employment in Pakistan. Retrieved April 06, 2021, from https://www.ncbi.nlm.nih.gov/pmc/articles/PMC6801594/

Martins, F. S., da Cunha, J. A. C., \& Serra, F. A. R. (2018). Secondary data in researchuses and opportunities. PODIUM sport, leisure and tourism review, 7(3).

Middle east respiratory syndrome coronavirus (mers-cov). (2019, March 19). Retrieved Nov 06, 2020, from https://www.who.int/news-room/fact-sheets/detail/middle-eastrespiratory-syndrome-coronavirus-(mers-cov)

Mike Allen, K. (2020, June 28). Airbnb ceo: Travel may never be the same. Retrieved Jan 11, 2021, from https://www.axios.com/airbnb-travel-coronavirus-3f7ac17c-89d7$4 \mathrm{ba6}-9 \mathrm{~b} 5 \mathrm{~b}-$

8905e4aa888a.html?utm_source=newsletter\&utm_medium=email\&utm_campaign= newsletter_axiosam\&stream=top

Nakazawa, E., Ino, H., \&Akabayashi, A. (2020). Chronology of COVID-19 cases on the diamond princess cruise ship and Ethical Considerations: A report from japan. Disaster Medicine and Public Health Preparedness,14(4), 506-513. doi:10.1017/dmp.2020.50

News article: World travel \& Tourism Council (WTTC). (2021, March 25). Retrieved April 10, 2020, from https://wttc.org/News-Article/Global-TandT-sector-suffered-aloss-of-almost-US4-trillion-in-2020

Pettinger, T., James, Shanthine, Lhamo, P., Aaliya, Girl, C., Eden. (2020, May 06). Sectors of the Economy. Retrieved April 09, 2021, from https://www.economicshelp.org/blog/12436/concepts/sectors-economy/ 
Pneumonia of unknown cause - China. (2020, January 30). Retrieved April 10, 2020, from https://www.who.int/csr/don/05-january-2020-pneumonia-of-unkown-causechina/en/

Rassy, D., \& Smith, R. D. (2013). The economic impact of H1N1 on Mexico's tourist and Pork sectors. Health Economics,22(7), 824-834. doi:10.1002/hec.2862

Read "global health and the future role of the United States" at NAP.edu. (2017). Retrieved Nov 06, 2020, from https://www.nap.edu/read/24737/chapter/6

Roy, B., \& Hoque, R. (2015). Building a Strong Brand Image of Cox's Bazar as a Tourist Destination: An Empirical Analysis on Cox's Bazar. American Journal of Tourism Management, 4(2), 27-34. doi:10.5923/j.tourism.20150402.01

Shane Harris, G. (2020, March 22). U.S. intelligence reports from January and February warned about a likely pandemic. Retrieved April 11, 2020, from https://www.washingtonpost.com/national-security/us-intelligence-reports-fromjanuary-and-february-warned-about-a-likely-pandemic/2020/03/20/299d8cda-6ad511ea-b5f1-a5a804158597_story.html

Thakur, K. (2018). Importance of tourism: Advantages of tourism: Economic importance \& benefits of tourism industry. Retrieved April 06, 2021, from https://marketwidth.com/blogs/Importance-Tourism-Industry-Economic-Value.htm

The impact of COVID-19 in tourism and hospitality industry of Bangladesh. (2020, May 13). Retrieved Sep 09, 2020, from https://www.newagebd.net/article/106347/theimpact-of-covid-19-in-tourism-and-hospitality-industry-of-bangladesh

Times, G. (2020, October 16). COVID-19 and domestic tourism development in Bangladesh. Retrieved Nov 28, 2020, from https://www.globaltimes.cn/content/1203686.shtml

Tourism - definition, types \& forms, history \& importance. (2020, August 09). Retrieved April 21, 2021, from https://tourismnotes.com/traveltourism/\#: :text=The\%20UNWTO $\% 20$ defines $\% 20$ tourists $\% 20$ as,from $\% 20$ within $\% 2$ 0the\%20place\%20visited'.

Tourism industry: Everything you need to know about tourism: Revfine. (2021, March 10). Retrieved April 09, 2021, from https://www.revfine.com/tourism-industry/

Tourism policy responses to the coronavirus (covid-19). (2020, June 02). Retrieved July 20, 2020, from https://oecd.org/coronavirus/policy-responses/tourism-policyresponses-to-the-coronavirus-covid-19-6466aa20/

Tourism Sector (BD Economy). (2020). Retrieved April 10, 2021, from https://www.scribd.com/document/490793239/Tourism-Sector-BD-Economy

U.S. Embassy Dhaka | 23 July, 2. (2021, April 13). COVID-19 information. Retrieved April 17, 2021, from https://bd.usembassy.gov/covid-19-information/

UNWTO world Tourism barometer and STATISTICAL Annex, January 2020. (2020). UNWTO World Tourism Barometer,18(1), 1-48. doi:10.18111/wtobarometereng.2020.18.1.1

V. A. (2021, March 10). Tourism industry: Everything you need to know about tourism: Revfine. Retrieved April 21, 2021, from https://www.revfine.com/tourismindustry/\#: : text=What $\% 20$ is $\% 20$ the $\% 20$ Tourism $\% 20$ Industry $\% 3 \mathrm{~F}$,-

So\%2C\%20what $\% 20$ is\&text $=$ It $\% 20$ is $\% 20$ one $\% 20$ of $\% 20$ the,of $\% 20$ additional $\% 20$ in dustries $\% 20$ or $\% 20$ sectors.

Wetsman, N. (2020, February 20). Coronavirus-contaminated cruise SHIPS mirror the global crisis. Retrieved Jun 12, 2020, from 
https://www.theverge.com/2020/2/20/21145315/coronavirus-cruise-ship-outbreakdiamond-princess-policy-impact

What is tourism industry? (2018). Retrieved Jan 10, 2021, from https://marketwidth.com/Tourism-Industry.htm

World tourism organization. (2021, April 09). Retrieved April 10, 2021, from https://www.unwto.org/news/international-tourism-arrivals-could-fall-in-2020 